\title{
Teachers' Perceptions Of The Value Of Research-Based School Lectures
}

\author{
Jonathan Black, Paul Curzon, \\ Chrystie Myketiak, Peter W. McOwan \\ Queen Mary University of London \\ London \\ \{jonathanb, pc, chrystie, \\ pmco\}@eecs.qmul.ac.uk
}

\begin{abstract}
A major challenge facing secondary schools is to encourage students to take computing courses. One approach is to invite external speakers from universities or industry to give lectures. The cs 4 fn project, a large UK-based initiative to enthuse students about computer science, includes this approach. Speakers from Queen Mary, University of London, visit schools to talk to students about computer science research. Our interactive talks tell engaging research-based stories on topics such as artificial intelligence and human-computer interaction as well as using magic tricks to illustrate computing principles. We asked teachers to complete post-talk surveys online; in particular we were interested in whether they believed students' perceptions of the subject had changed. They reported that their students' views of computer science were improved, and that they felt students were more likely to take classes in computing in the future as a result of the talk.
\end{abstract}

\section{Categories and Subject Descriptors}

K.3.2 [Computers and Education]: Computer and Information Science Education - Computer Science Education

\section{General Terms}

Human Factors.

\section{Keywords}

Public engagement, outreach, recruitment, K-12, schools, teachers, lectures, magic.

\section{INTRODUCTION}

A range of studies have looked at the effectiveness of lectures in higher education contexts, (e.g., Cooper \& Foy, 1967) including those focusing on particular lecture styles such as PowerPoint lectures (e.g., Bartsch \& Cobern, 2003) Despite the popularity of the lecture approach in outreach activity, there is little published evidence about its effectiveness against the aims of public engagement activity and of its value in this context. This may be because organised computer science engagement projects are often workshop-style. Lecture-style approaches may be happening 'under the radar', missed out of evaluation work on workshopstyle programmes. However, the lecture style is widely used and warrants study.

The cs4fn project (Curzon, 2007) highlights the importance of flexible 'take-away resources' such as magazines and booklets rather than focusing just on workshops or lectures. We have found that this increases motivation and supports teachers (Myketiak et

\author{
Laura R. Meagher \\ Technology Development Group \\ Dairsie, Fife \\ Laura.Meagher@btinternet.com
}

al., 2012). Curzon et al (2009) present evidence for the success of this approach in engaging with potential students.

In previous work we have surveyed audiences for our magic shows and showed their popularity with students (e.g., Curzon \& McOwan, 2008). In this paper we evaluate the effectiveness of a lecture approach, surveying teachers about their own views and those of their students after seeing a talk. We focused on a range of indicators about the value of the talks but with a particular emphasis on their value in inspiring students to take their computing education further. We show that this kind of researchbased interactive lecture is highly valued by teachers and they believe it is effective in encouraging students to consider taking the subject further both at school and university.

\section{METHOD}

We present feedback from two separate lectures given 19 times in the 2010-2011 and 2011-2012 academic years. We use audience volunteers in kinaesthetic activities to illustrate core concepts. The lectures also focus on telling engaging research stories. They do not attempt to cover curriculum topics directly, nor do they directly cover career choices or discuss university courses.

Each time we delivered a talk at a school, we solicited a response to an online survey from the teacher. This meant the responses could be anonymous and gave the teacher an opportunity to talk to the students about the talk before filling out the survey. The survey consisted of 16 questions. We asked teachers to identify the lecture title, and which team member delivered it. The survey went on to ask general (non-identifying) details about the audience and the school that hosted the talk. There were then a series of Likert scale questions about the value of the approach, two yes/no questions followed by a series of open questions.

\section{TEACHERS' PERCEPTION OF THE VALUE OF THE LECTURES}

\subsection{Quantitative results}

The survey received 19 teacher responses. We asked the respondents to give an overall view of the lecture with options on a 5-point scale. All $(100 \%)$ were positive. $89.5 \%(n=17)$ gave the highest rating (very good) while the remaining 2 teachers rated it as good. Respondents were also asked if the lecture met their needs and if they would recommend the lecture to other schools/teachers, with yes/no options in both cases. All 19 teachers $(100 \%)$ responded yes to both questions.

When asked about students' opinions, 84.2\% ( $\mathrm{n}=16)$ strongly agreed that their students had enjoyed the lectures with the remaining 3 agreeing. None were neutral or disagreed. $78.9 \%$ 
$(n=15)$ strongly agreed that their students found the lecture interesting while the remaining 4 agreed - a $100 \%$ positive response. $73.7 \%(n=14)$ strongly agreed that the lecture had improved the students' understanding of the subject with the remaining 5 agreeing.

The last question in this section asked whether some students had changed their view of computer science in a positive way. $36.8 \%$ $(n=7)$ strongly agreed. $42.1 \%(8)$ agreed and the remaining $21.1 \%$ were neutral. We asked whether, as a result of the lecture, one or more students were now more likely to consider taking computing subjects further at school. $20 \%(\mathrm{n}=3)$ strongly agreed with this statement, $53.3 \%(n=8)$ agreed (i.e. $73.3 \%$ of responses were positive) and the remaining 4 were neutral. Four teachers did not answer.

We asked a similar question about students' university choices. In response, $23.5 \%(n=4)$ strongly agreed that one or more students were more likely to go on to take the subject at university, $52.9 \%$ $(n=9)$ agreed, meaning $76.4 \%$ of responses were positive. A further $17.6 \%(\mathrm{n}=3)$ were neutral, 1 person strongly disagreed and $1 \mathrm{did}$ not answer the question. The teacher who strongly disagreed was otherwise very positive about the lecture, and did not suggest any improvements. It is unclear why they answered the question the way they did.

\subsection{Comments}

The comments in response suggest that teachers believe the form of a lecture affects student enjoyment as much as its content. A typical comment said, "The lecture was fast-paced, dynamic and really challenged the students [...] This was a very appealing way to promote the study of ICT." Another teacher approved of "the mix of talking, video and practical examples." Many others mentioned that the kinaesthetic activities were the students' favourite parts of the lectures. Comments by teachers on the benefits of the interactive elements followed a couple of themes. Some mentioned stylistic benefits (e.g., increasing student enjoyment and engagement), while others mentioned contentrelated benefits (e.g., modeling of computer functionality and opening students' minds).

\section{DISCUSSION AND CONCLUSIONS}

We have evaluated teachers' perceptions of the value of university lectures taking place in schools. This involves lectures that draw from research topics and involve interactivity using a kinaesthetic approach. In particular we focused on teachers' perceptions about the immediate effect of the lectures and whether it had changed students' attitudes to taking the subject further.

Teachers were confident that their students had found the lectures interesting and now understood the subject better. They were less strong but still very positive in their agreement that the lectures had changed their students' perception about computing, and that they had influenced students' plans for the future. This may reflect the difficulty of one lecture to change overall perceptions or future plans, but it may also simply be a reflection of the difficulty teachers face in assessing and reporting students' views.

\section{FUTURE WORK}

This pilot study examined teacher responses to 19 lectures about computing. We hope to gather more responses in a larger study to come. We also intend to gather more direct and in-depth data on student perceptions. Finally, we are in the process of collecting and analysing recruitment data to examine the ultimate effect of talks on recruitment at university. Whilst this study has focused on the value of such talks to teachers, this ongoing work will explore the value to universities.

\section{ACKNOWLEDGMENTS}

The cs4fn programme is funded by EPSRC research agreement (EP/F032641/1) with additional support from Google's CS4HS programme. CHI+MED: Multidisciplinary Computer-Human Interaction research for the design and safe use of interactive medical devices project is funded by EPSRC research agreement EP/G059063/1.

\section{REFERENCES}

[1] Bartsch'R.A. \& Cobern, K.M. 2003. Effectiveness of PowerPoint presentations in lectures, Computers \& Education, 41 (1) August, 77-86, Elsevier, DOI= http://dx.doi.org/10.1016/S0360-1315(03)00027-7

[2] Cooper, B. \& Foy, J.M. 1967. Evaluating the effectiveness of lectures, Higher Education Quarterly, 21(2) 182-185. March. DOI: 10.1111/j.1468-2273.1967.tb00231.x

[3] Curzon, P. 2007. "Serious Fun in Computer Science", 12th Annual Conference on Innovation and Technology in Computer Science Education, organised by the ACM Special Interest Group on Computer Science Education (SIGCSE), ACM SIGCSE Bulletin 39(3) p1, DOI: $10.1145 / 1269900.1268785$

[4] Curzon, P., Black, J., Meagher, L.R., McOwan, P.W. 2009. "cs4fn.org: Enthusing students about Computer Science", Proceedings of Informatics Education Europe IV, Christoph Hermann, Tobias Lauer, Thomas Ottmann and Martina Welte (Eds.), pp73-80, Freiburg, Germany, November.

[5] Curzon, P. \& McOwan, P.W. 2008. "Engaging with Computer Science through Magic Shows", ITiCSE 2008, The 13th ACM SIGCSE Annual Conference on Innovation and Technology in Computer Science Education, ACM SIGCSE Bulletin 40 (3), pp179-183. June 30-July 2, Madrid, Spain. DOI: $10.1145 / 1384271.1384320$

[6] Myketiak, C., Curzon, P., Black, J., McOwan, P.W., and Meagher, L.R. 2012. cs4fn: a flexible model for computer science outreach. In Proceedings of the 17th ACM annual conference on Innovation and technology in computer science education (ITiCSE '12). ACM, New York, NY, USA, 297-302. DOI: 10.1145/2325296.2325366 